\title{
REALITY AND METHODS IN DOCUMENTARY FILMMAKING
}

\author{
LÁSZLÓ TARNAY \\ University of Pécs \\ tarnay.laszlo@pte.hu
}

\begin{abstract}
The method and the formal-technical language of documentary filmmaking have expanded so much that the traditional divide between documentary and fiction cannot be reasonably held. Animation has also claimed its place among the possible devices of a documentary film. Consequently, a documentary no longer wears its 'truthfulness' on its sleeve. The cues of documentary that were used historically, like archival footage or talking heads, are eclipsed by cognitively engaging interactive camera work provoking viewer's identification. The dilemma that a would-be documentary filmmaker is necessarily confronted with is between perceptual realism and representational realism. An image cannot show the 'original': it can only declare it in a meta-communication about the image. In the history of film the self-referential 'dead-end' of the 'ontological' image is expressed by a camera filming the 'eye' of another camera. The self-referentiality of documentary filmmaking also entails that documenting is necessarily gappy: it always leaves certain things unsaid or hidden. The story it tells has its own important lacunae. It is the Unsaid of a documentary, and not so much the representation's truthfulness and that constitutes the ethical source for the viewer.
\end{abstract}

Keywords: aboutness, documentary, animation, interactivity, ethics, subjectivization, disposition to intervene, unsaid

\section{The Aboutness-relation and the Ontology of the Documentary}

Documentaries are meant to be about reality. The only intriguing question is how we can know that a documentary is indeed about reality. The theoretical debate how to differentiate between fact and fiction goes back almost 50 years. According to a promising idea reality is independent of our mind and thus of the image representing it while fiction is mentally construed. Such an ontological difference, however, is of no practical use when we ask how we can know whether or not what we see in a film is "fact or fiction". No wonder that the term 'documentary' became obsolete around 1960s when Sadoul wrote that "it is not simply the truth that one records", ${ }^{1}$ and was replaced by a series of terms like «cinema vérité», direct cinema, observational cinema, etc. which were intended 
to convey that the film is in immediate proximity with reality. But being close to reality would not help, either, in knowing whether what we see is about reality. Clearly, the aboutness-relation is a semiotic relation. We do not ask ourselves when we see, e.g. a tree whether it is a real tree for our perception is indeed in immediate proximity with the world: normally, it is veridical. But seeing that tree in a documentary would be mediated through and by the images. Moreover, it may be doubly mediated if the photographed tree is seen as part of a fictional scene. Bazin's ontological realism would predict that the images of the tree is about that real tree which stood before the camera at the moment of shooting, it is a nominal portray, while its image in a film stands for a fictional tree. The semiotic aboutness-relation is then a second-order relation which may or may not be parasitic on the first. The image need not be about a real tree in the first place in order to refer to a fictional tree for it can be drawn either manually or digitally. A documentary blocks the introduction of a second-order aboutness-relation. However, blocking fictional representation is not sufficient to warrant aboutness at the first ontological level if there isn't any noticeable difference between a real tree, its photographed image and its potential fictional counterpart. It is the case in most lifelike visual representations from historic trompe-l'oeil paintings, the photograph to digitally simulated interaction. It is this illusionary effect that mock-documentaries makes use of.

Take, for example, the new David Attenborough series, Planet Earth II, which was shot with the use of the most modern technology, including drones. The viewer experiences gliding with the monkeys from tree to tree, hunting antelopes with the big cats or diving with the crocodiles. Interactive documentary opens up a wholly new phase in the history of film in that it accomplishes what Dirk Eitzen described as the disposition to intervene which constitutes "the crucial difference between documentary and fiction films". In other words, a documentary is a film which "depicts a place where our actions would have made a difference". ${ }^{2}$ Note that the concept of the documentary entails both that we are removed from the world portrayed in it and that, were it possible, we are disposed to intervene in it. In contrast, we can be easily immersed in fiction practically without limit and not feel necessarily the incentive to act in it - although interactivity is the most appealing feature of moving images today. Accordingly, while 'normal' documentaries depend on the past conditional possibility of interaction, interactive documentaries today shot with modern digital technology offer that possibility almost unconditionally. However, since there is no difference in the visually embodied perception of a digitally produced documentary and a fictional film the claim that documentaries come with an awareness of the inclination to intervene can no longer be substantiated. Unless we know independently that the film is about reality our inclination is nonspecific: it is caused by the high level of simulation that the filmic images exemplify. Is it the end of documentary film making or just 
the beginning of a new era of documentaries through which we can intervene in their world, that is, reality?

My suggestion is that the answer depends on the use of technology. If an image-making device like a virtual reality helmet is used as a means of getting to know and making our way in the world in which we are embodied - be it the real or a simulated world - the device (and the images generated) become prosthetic: they function as sensory aids integral to, or inbuilt in, the body. Prosthetic applications dispense with the original aboutness-relation and reinstate a digitally improved direct perception. ${ }^{3}$ However, we can still treat the images, simulated or not, as being about something other than themselves. It is precisely what Planet Earth II presupposes: it is still about the same world Planet Earth showed us. In other words, images constitute a means to access past, present or maybe future reality in which we are not necessarily embodied. But if this is the case, the indistinguishable character of documentary images and images representing a fictional world may turn out to be the end-all of the documentary. It is my firm belief that in order to avoid such a negative result documentary filmmaking has always tended to foreground certain traits which were meant to distinguish documentaries among the totality of films. The traits functioned historically - before the advent of fully interactive 3D documentary - as a perceptual correlative of the ontological difference between fact and fiction. Without such a correlative documentaries would be indistinguishable from fiction, the distance between us as viewers and the filmic world would collapse, and our awareness of an inclination to intervene would evaporate.

\section{Features of the Documentary}

The distinguishing features of the concept of documentary can be arranged along two axes. The first axis is history. The forms of filming technique and film language historically functioned as cues of reality. The cues depended on the actual state of film technology. The list ranges from black-and-white archival footage to diversely corrupted or corroded filmstrips including granular images, private video footage, jerky handheld camera, unfocused images, speaking heads, etc. Thus documentaries are redefined every time there is a change in filming technique or viewing strategies or both. The image features mentioned above have both a strong distancing and an emotional effect. They create a distance between the viewer and the world portrayed and at the same time elicit the awareness of an inclination to intervene. The double-sided effect explains partly why animated documentaries can be perceived as documentary. For animation appears at the end of the scale of devices which remove the audience from the spatiotemporal world of the images by blocking perceptual identification with the charac- 
ters while evoking fierce emotional reaction. As Orly Yadin explains animated documentaries have two important advantages vis-à-vis ordinary documentaries: firstly they can show the viewer locations which are either unreachable through photography or no longer exist. Secondly, they are less exploitative of its subjects by being less voyeuristic and less encroaching upon its subjects' personal domain. ${ }^{4}$ In both cases animated documentaries prevent the viewer from perceptually identifying with the subject while by other means like non-diegetic narration elicit a strong emotional response.

The other criterion that qualifies images as documentary derives from visual cognition. Vision, among other senses, affords certain actions. For example, perceiving the door of the house affords entering it. Recorded images, however, block the action-oriented perception of the visual world or re-assign it to the character(s). Seeing a door in a film is perceiving an affordance available to the character present in the shot or scene. ${ }^{5}$ In contrast, assimilating character's and viewer's vision by simulating the vision of the character through POV or advanced visual technology contributes to the immersion of the viewer in the represented world and increases the potential of intervention. While the traditional cues of reality preserve the spatiotemporal distance between viewer and the world portrayed the cognitive effects of contemporary digital interactive technology eliminate that distance by embodying the viewer in the projected world and creating an "online" feeling that he or she can intervene in it.

The dilemma with which a would-be documentary film maker is necessarily confronted is between perceptual realism and representational realism (in correlation with ontological realism). While it seems that the future will be dominated by new interactive technology the traditionally realist methods still carry a kind of authenticity that the events and characters in the film are real or close to real. Most commonly, the method that documentary filmmakers apply consists of utilizing and combining different filming techniques in a single "documentary". The complex method is in fact an assembly of filming techniques that different schools or tendencies made popular in the past 50 years or so. Cinema vérité, direct cinema, observational cinema, anthropological or etnofilm are some of the most influential ways of filmmaking that historically replaced the idea of 'documentary' from the 1960s. The term 'documentary' carried strong overtones of truth associated with Dziga Vertov's idea of kino Pravda. Although the term 'truth' did not disappear, the filmmakers are ready to acknowledge that recording reality also changes it. The presence of the camera cannot be ignored including the effect that it produces on the world to be documented. If the camera is participatory, what it documents is the interaction of the filmmaker and the world he or she wants to record. The film is authentic not because it shows the reality-in-itself of the world but because it records the filmmaker's intervention in a world unknown to him or her. Thus the film is not so much true, 
but truthful, direct, sincere, honest, etc. However, when it comes down to a complex method of a garden variety of historic devices from interviewing to non-diegetic narration, the net effect may be more disconcertaining or equivocal than highly realistic whatever it would mean. The reasons are not entirely clear. Maybe, it is that there is no unambiguous sign where the intervention of the filmmaker begins and ends. Maybe the audience response is too governed by the visual conventions and cognitive effects of fictional films to be able to distil a specifically 'documentary' meaning. When, for instance, during the shooting of Jafar Panahi's film, The Mirror (1997), the child actor, Mina suddenly steps off the bus protesting against the shooting and the microphone remains attached to her Panahi continues to shoot the scene, which avowedly was not planned. The child's abrupt protest became an integral part the film and in his autobiographical film, This Is not a Film (2011), Panahi compares the scene of Mina removing her cast to his own state of house arrest. In his latest work shot clandestinely in Teheran's streets, The Taxi Tehran (2015), Panahi's passengers are real amateurs who talk about their own problems. The film is almost like a documentary, however, not everything they do is spontaneous and we feel Panahi directed them and compressed too much in too short a film.

To sum up: there is no guarantee that what we see is indeed a true copy of - quoting André Bazin again - what took place in front of the camera at the moment of shooting. The complex method may convey a documentary or realist feeling to the audience but it remains essentially assertive: the filmmaker declares, either explicitly in advertising copies, promotional materials or public debates, or implicitly by filming technique which traditionally cue reality that his or her film is about reality. As the title of Panahi's film, This is Not a Film, borrowed from René Magritte's philosophical painting, Ceci n'est pas un pipe, indicates, the aboutness-relation of any documentary artwork suffers from an infinite regress (or a vicious circle): whether the image is indeed about a real pipe or a real amateur can only be declared at another level of communication or in a meta-work. In the history of film the self-referential 'dead-end' of the 'ontological' image is expressed - once again quoting Magritte's painting of a man reflected in a mirror, Not to Be Represented ${ }^{6}$ - by the image of a camera filming the 'eye' of another camera. The moral is that an image cannot self-referentially show that it is about reality. It can only declare that it is in some separate communication. I would like to illustrate the declarative character of documentaries with two characteristic examples from Hungarian film history. The first is historical, the second contemporary. 


\section{The Declarative Character of Documentary: Fotográfia}

First I would like to consider briefly an avowedly fictional film by Pál Zolnay, titled Fotográfia (Photography, 1973). The film recounts the story of a photographer and an editor whose task is to develop and retouch the pictures. They wander from village to village offering people to make portraits of the villagers which the villagers can hang on the walls. Soon, however, people start to show the photographer and the editor their own photo albums, images taken in the past, telling stories about themselves and their family members. After a couple of scenes at the house of an elderly couple a thrilling story unfolds about the first wife of the now invalid husband, a retired postman, who killed her two daughters and attempted to commit suicide. She survived, however, and after being incarcerated for years, now she lives alone. The final episode of the film takes us to the house of the old murderous woman. Having heard earlier the rumor version of the killing from the second wife of the postman, we are eager to learn about the mother's motives. We wait patiently with the camera outside the fence when the photographer tries to make the woman confess. But she is over-resistant and withdraws inside the house. Then there is a cut and next we are placed at an ambiguous point neither in, nor out of the house. Slowly we realize that the image we see is a reflection on the window taken from the outside while the dialogue between the old woman and the photographer we hear from the inside. That we are positioned on the paradoxical boundary between the outside and inside is further enhanced by the double 'reflection' on the window glass: on the one hand we see the outward reflection of the photo-editor who is walking to-and-fro in the garden and is trying to peep in; on the other hand we see the photographer inside through the glass so that his 'reflection' is projected over that of the editor. The windowpane is like a transparent canvas on which reality and the reflection of reality are equally reflected. It is an impossible place where the camera shut out of the house and the audio recorder inside the house meet. It also constitutes the audience's position, thus unifying literally the two spaces while the filmmakers (photographer and editor) are physically separated by the very same glass which is both a transparent and a mirroring plane. Placed literally at the crossroads of inside and outside, the windowpane is also an embodied metaphor of directly (audio perception and peeping through) and indirectly experiencing reality (reflections on the glass). My suggestion is that the recording and viewing situation is also a metaphor of the documentary mode of filmmaking. The ontological ambiguity of the windowpane is further enhanced by the film's narrative. Although our desire to become privy with the old woman through the camera comes true - however ambiguous it is - we would never know her 'real' reason for the killing. The woman would not tell the photographer, and thus us, what pushed her to the brink of existence 
where killing is release from the tension of family life. The only things we come to know is that her postmaster husband was torturing them. The rest remains forever hidden from us.

\section{The Ethical Asset of Documentary}

Now we know from other sources that many parts of the film were shot as a documentary. Especially the last scene at the house of the murderous woman. The filming team was indeed shut out of the house and it was the director who, after much hesitation, mastered his nerves and entered the house. The film proves to be true not only to the story but to the circumstances of the shooting: the intervention of the filmmaker. Fotográfia shows not only that the fictional/documentary divide is not waterproof from the fictional side but that documenting is necessarily gappy: it always leaves certain things unsaid or hidden. The story it tells has its own lacunae. In other words, documentaries are not 'objective', or fully observational. Just as there is no omniscient viewpoint in reality there is no objective position to film reality. Consequently, the modern documentary filmmaker cannot aspire to give a full and impartial picture of anything 'real': the only thing he or she can attempt to do is to document his or her intervention in it. Thus, Zolnay, although he fictionalizes it, creates a situation in which both the potential and the limits of his intervention in the elderly woman's life are reflected. He does not try to cover up the lacunae in her photographically illustrated story. Thus, the unsaid in a documentary may turn out to be as significant as what is said and shown. Moreover, it may add to its authenticity in that the film would not claim to know what it does not know or would remain silent on issues which might influence the audience's assessment of the character(s). In most cases such issues belong to the private sphere, and the filmmaker's ultimate decision to share it with the public is deeply ethical.

Although our age is determined by the right to unrestricted visibility meaning that what is not visually shared does not exist, ${ }^{7}$ and consequently, that the public sphere encroaches upon the private domain and would, in time, make it disappear, ${ }^{8}$ anyone shooting a documentary still faces the ethical dilemma whether it is legitimate to share visual and other information about its subjects with the audience-information which the subjects never meant to be divulged. Even Werner Herzog who is famous, and rightly, for many excellent documentaries was seriously criticized for the violation of the ethical norm of privacy when making his fictional documentary, The Grizzly Man (2008), about Timothy Treadwell. Herzog appropriated Timothy's self-made videos, re-arranged and re-edited them. He also added his own commentary and the interviews he conducted with his parents and people who liked or knew him. Treadwell, who claimed to be the "saviour" of 
the Alaskan grizzly bear but was to be brutally killed, together with his girlfriend, Amy, by a wild bear, shot hundreds of hours of videos mostly all alone speaking to the camera railing at the rangers of the national park, confessing things about his life, etc. Most dramatically, the camera was standing on a tripod in front of their tent and was running when the bear attacked Timothy. Although the cap lens was on and no image was recorded the tape preserved Timothy's voice as he was trying in vain to send his girlfriend away till he passed away. Nobody ever listened to that tape until Herzog came. Although he did not share that dreadful experience with the public - a truly ethical gesture - he did reshape Timothy's personality so as to make him resemble a maniac in the film. Herzog not only reinterpreted Timothy's videos but provided a psychologically integral picture of his personality. Thus, he may be guilty of using and abusing Timothy's private videos only to re-create him as a mentally ill person. If so, he violated the ethical norm of documentary filmmaking not simply in showing more of his character's private persona than he should have but by re-arranging Timothy's visual "selfportraits" and investing them with a new kind of meaning. ${ }^{9}$

\section{The Children of Cain}

Here I cannot go deeper into the debate whether Herzog had the right to do so. Instead I propose to discuss at some length the contemporary documentary Children of Cain (2014) by the young Hungarian filmmaker, Marcell Gerö. The film tells the story of three middle-age men, Pál, Gábor and Zsolt, who in their teens committed murder and spent 12-15 years in juvenile prison. Gerö uses shots from a film made 30 years before by András Mész Monory called Bebukottak (The Fallen Ones, 1985), which is a classical documentary consisting mostly of interviews with six boys who were incarcerated for murder in the juvenile prison in Tököl, Hungary. Gerö decided to track down three of them to see how they managed to integrate into society. His new documentary showcases the complex method described above. He includes cuts from Monory's film as archival footage. But he also conducts both classical and non-classical interviews with the now grown-up men and their family members. While the ex-criminals have long monologues about their guilt and their present conditions of life, and they speak directly to the camera, interviews with family members are more like Jean Rouch and Edgar Morin's ground-breaking Chronique d'un eté (1960), in which the filmmakers sat around the dinner table with the family while 'interviewing' them. In cinema vérité the camera is first made familiar to the people until its presence becomes unobtrusive or neutralized. Whether the process of familiarization requires a day, a week or months depends on the social milieu of the characters one would like to work with. Talking about his approach, Gerö explained that he spent four years 
with his subjects to get them used to the camera and he shot hundreds of hours of video before he started to edit the footage into a feature-long film omitting a great deal of scenes., especially comic ones. While during the shots he himself is not visible, we can hear his voice every now and then, and more importantly, we hear the people call him by his first name which indicates they are on friendly terms. He also claims that none of the scenes was premeditated and neither were the characters instructed what to do. There must have been at least one exception, however. When Gerö interrogated Zsolt's mother (not in the film) about his son's youth she gave confusing answers. At this point he selected a go-between, a mediator from among the mother's acquaintances in the village and instructed her to chat nonchalantly with the elderly mother while asking the questions he wanted to ask. She still would not tell much (she can't even remember when she bore her son) so that, like at the end of Fotográfia, we are left in the void and have to do with a few vague allusions to what seems to be a kind of psychopathological relationship between her and her son.

The participatory or interactive role of the camera is most conspicuous in the opening and closing scenes where the director addresses Pál's children about their father. The girl responds rather clumsily as if talking about her father would be embarrassing for her. Here the camera is not trying to hide its presence, but rather acts it out. It is not that performative as, for instance, Joshua Oppenheimer's The Act of Killing (2012), a film about the 1965 mass murders in Indonesia in which the perpetrators of the killings are allowed to reenact, reconstruct, comment upon and even fictionalize their horrible deeds. But the children, like Oppenheimer's actors, also become, to a certain extent, authors of the film. ${ }^{10}$ The scenes they figure in are in a way improvised like their responses to the director's questions such as "Okay, let's move on" meaning: "Right, what's your next point?" It may appear to be improvised because Gerö's documentary is an "extract" of four years co-existence with the families whereas Oppenheimer directly staged the tragic events of the past in the present. The edited version of The Children of Cain is in fact an allegory of the 'real' film, a filmed version of reality with its accidental and routine, singular and repetitive, individual and social activities. Obviously the director's aim was to look for the motivations for committing the crimes but it is equally clear that the confessions we hear in the film came accidentally and unexpectedly during the four years of shooting. Although the confessions may shed some light on the circumstances of the actions in the past, the present lives of the grown-up characters seem considerably undetermined. As Gerö puts it in an interview, all the three men would have the possibility to change their lives for the better, to make use of their independence or to turn to their families, instead of doing nothing like Pál or living homeless like Gábor or being hospitalized again and again like Zsolt. However, in some undefinable way, they all prefer living marginalized. Gerö stresses that it is their 
own decision to remain locked up in their own worlds. It is the most tragic consequence of their imprisonment, more tragic than the crimes they committed in the past.

\section{The Documentary-Fictional Debate Reconsidered}

The similarities between fictional films and documentaries are clear. Disregarding the historical references of the narrated events both fiction and documentary aim at character description, either subjective or objective, and attempts to evoke sympathy in the viewers. They both narrativize history and reveal how people are living their past in the present. We have seen the traditional and mostly technical cues of historic reality no longer distinguish documentaries from fiction for the methods of subjectivization of the moving image from handheld camera to granular imagery, among many other technical and narrative cues, have been thoroughly adopted by fictional cinema. At least it is what works in mock-documentary such as Dusan Makavejev's W.R.: Mysteries of the Organism (1971), Ruggero Deodato's Cannibal Holocaust (1980), Woody Allen's Zelig (1983) as well as the special film aesthetics of the Dogma Manifesto or The Blairwitch Project (1999) seem to have proved. What remains of the old documentary-fiction debate is the question of the ethical attitude of the filmmaker vis-à-vis the referential basis of his or her film. Timothy Treadwell of The Grizzly Man could have never existed, his videos could have been faked like the ones in Cannibal Holocaust, and Herzog's film would be equally thrilling. But it would not raise the same ethical questions it has raised.

We have also seen that in the age of visibility the diving line between private and public is evaporating. If what is publicly shared or posted is what exists the referential basis of images cannot be even formulated: the indexical picture of the real (whatever it means) would be tantamount to the picture (fictional or documentary) shareable in visual media. The reality of the image can be referenced only in a meta-discursive practice which is meant to accompany and evaluate the images. In a paradoxical and circular manner because nothing would better guarantee the referential basis of discourse than a picture. Consequently, if there is an ethic of the image it can sanction only the circulation of images but not the making of it. It is precisely the right to visibility - as Daniel Dayan puts it - that makes The Grizzly Man especially sensitive to criticism. But the ethical question that The Children of Cain raises is of entirely different kind. The film is immune of the porosity of the private/public divide for it wholly respects the personal rights of the three characters. The director had formally and substantially agreed with them that they can stop or censure the shooting at any time they feel it obtrusive or unjust. If we feel uneasy watching the film, this is not so much because of what 
they say or do; it is rather that the scenes probe our comfort zone and question our thoughts about the world, about social coherence, exclusion and justification, and maybe even about what is right or wrong. If documentaries evoke the disposition to intervene The Children of Cain aborts such a disposition. As Marcell Gerö admits during the four years of shooting it was almost impossible to 'intervene' in the three men's lives. But it is also the impossibility to intervene that opens the ethical dimension in the viewer. It is the Unsaid of the film that frustrates the viewer's response. Gerö's approach is more sympathizing than overtly objective and distancing: it engages the viewer both intellectually and emotionally. It is the frustration that there remains forever a distance in the 'intimacy' or closeness that the film creates, a distance that the viewer cannot overcome.

Today, documentaries do not stand apart from fiction films through the sheer use of technology and narrative content. No wonder that documentary filmmaking have embraced various forms of animation, which constitute a further step away from the indexical or referential basis that once guaranteed the authenticity of documentaries. In the short animated documentary, Silence (Sylvie Bringas \& Orly Yadin, 1998) it is the personal experience of the narrator, Tana Ross, rather than the archival cuts of fascism, that renders the film 'documentary'. ${ }^{11}$ Accordingly, documentaries are on an equal footing with fiction with respect to 'reality' whatever it can be but they still differ from fiction films in the nature and the intensity of viewer's response. Documentaries are more likely to question the viewer's attitude, stereotypes and conventions than fiction films. The tables are turned: it is the documentaries that tend to intervene their viewers' lives than vice versa. As Silence exposed racism in Sweden The Children of Cain questions our prejudices about young criminals as well as our faith in social institutions. When we are confronted with the victimization of the three men from their childhood living a life full of humiliation and being shamed by their family and others, our sympathy is heightened and our sense of moral judgement shifts toward the social environment. But we, the audience are also part of that environment. If we cannot intervene in the characters' lives we could intervene in that environment - our environment.

Whether it is the impossibility of integration or the vicious circle that crime and poverty feed upon each other that conflicts with the disposition to intervene, the frustration we feel heightens our ethical stance: how do we judge the situation of social outcasts? Can we dispense with the stereotype and routine reactions and see them in a different light? Are we ourselves prejudiced as the three men's relatives, mother and children are? It is in the context of the preceding questions that a certain criticism of the film's undue aestheticization is arguable. The almost black-and-white photography and visual language, the minimalist score, the otherwise puzzling and repeating blackouts within the archive footage of the older documentary, The Fallen - they all attenuate the unsettling effect of the docu- 
mentary. Undue anesthetization brings the viewer's experience closer to that of a fictional film and does away with the disposition to intervene and consequently, causes less ethical concern. To put it roughly and generally, too much beauty can embellish the ugly, the emotionally stirring, or even the horrible. But while in fictional art aestheticization may add to the poetic or lyrical effect and thereby enhance the emotional level of the work, in documentary it neutralizes its ethical charge. In contrast, in animated documentaries like Silence the aesthetic quality and the lyrical effect generated by it heightens the subjective and personal drama of the narrator rather than tempering with it. As a conclusion we can say that although documentary filmmaking has embraced a wide range of filming technique associated with fictional film its "peculiar appeal" stays with us for some time, at least until the real world preserves is appeal vis-à-vis virtual space. But documentaries about virtual reality are not far in the making. When interactive documentaries have full sway differences between distant and proximal, subjective and objective, filmmaker and film viewer will ultimately collapse.

\section{References}

Dayan, Daniel, 2013. Conquering Visibility, Conferring Visibility: Visibility Seekers and Media Performance. International Journal of Communication 7 (2013), 137-153.

Eitzen, Dirk, 2005. Documentary's Peculiar Appeal. In: Anderson, J. D. and Anderson, B. ed. 2005. Moving Image Theory: Ecological Considerations. Carbondale: Southern Illinois UP, 183-199.

Graff, Séverine, 2011. "Cinéma-vérité" ou "cinéma direct": hasard terminologique ou paradigme théorique? Décadrage 18. [online] Also available at: https://decadrages.revues.org/215 [Accessed 19 November 2016].

Nánay, Bence, 2005. Merleau-Ponty és a film. Akció és percepció a moziban. Metropolis 8/3 (2005), 52-61.

Török, Ervin, 2016. Az ölés aktusa és A csend képe. Apertúra, 2016/nyár. [online] Available at: http://uj.apertura.hu/2016/nyar/torok-az-eljatszott-tortenelem-az-oles-aktusa-es-a-csend-kepe/ [Accessed 19 November 2016]

Yadin, Orly, 2003. But Is It Documentary?" In: Haggith, Toby and Newman, Joanna ed. The Holocaust and the Moving Image. Representations in Film and Television Since 1933. New York: Wallflower Press. [online] Also available at: http://www.yadinproductions.com/but_is_it_documentary.htm [Accessed 19 November 2016].

\section{Notes}

1 «On ne fait pas simplement de la vérité en l'enregistrant !» Quoted by Graff 2011.

2 Eitzen 2005, 180.

3 Of course, we can be deceived about what we perceive just as we can be deceived by mirages or other atmospheric phenomena or optical illusions. But it does not mean that what we actually see we does not see directly but mediated by projected images. We may reflect on how much we can trust our prosthetic eyes just as we may question what we see with our organic eyes. But that is all. 
4 See Yadin 2005.

5 See Nánay 2005.

6 Magritte's painting is paradoxical. It depicts a man standing in front of a mirror, but whereas the book on the mantelpiece is reflected correctly, the man can see only the back of his head. That is the 'original' face cannot be shown in a mirror. True reality necessarily escapes representation.

7 Most probably, strongest evidence to now is the case of Abu Ghraib, the US military prison in Iraq. The story of torturing and abusing Arab prisoners by their American guards came to light in 2002 when the first photos appeared in Newsweek. Later on, Errol Morris shot a classical documentary, Standard Operating Procedure (2008), about the guards' motives for the sexual abuses and not less significantly, for visually recording the tortures. One of the key moments in the film is when the American ex-soldiers affirm that they made the photographs for their own pleasure and they would never have thought of making them public. Even if it were so it proves ironically that any photo ever made - despite the tree intention of its maker - is meant to be seen, especially in a world where visibility is all there is, that is, where the relation between photograph and reality is reversed. As a result, Being and Image becomes one.

8 Dayan 2013 argues that in our age the right to visibility replaced the freedom of the press and truth has become a question of mostration. By the latter term he means that truth is essentially performative: ti is a media event and not anything like an indexical or ontological relation.

9 To be fair to Herzog it must be noted that Treadwell's habit of recording himself and the bears may itself be a kind of self-treatment by means of which he tried to process the traumas he experienced earlier in the civil society.

10 Török 2016 argues extensively that there is a difference between postmodern and postclassical documentaries. While The Act of Killing belongs to the first, its continuation, The Look of Silence belongs to the second category. The main difference between them is that while postmodern documentaries stage events from various historic and social angles together with a clash of opinions postclassical documentaries show the events through the private lives of individuals focusing on their emotional responses and intimate scenes, i.e. they subjectivize and privatize history. The Children of Cain, however, displays features from both category. It showcases the private lives of three people voicing deep social criticism. On the other hand it also sets up a common narrative frame of their lives, a social perspective in which they all appear victimized worthy of our sympathy, maybe to the point of being acquitted of their crimes. Such a consequence would not normally follow from the postmodern documentary because of the irony that a multi-faceted approach is steeped in. In contrast, a subjectivized account of events may well end up with evoking deep sympathy with the actors. The Children of Cain lack the ironic overtone even though the director admitted that he did mean to produce a depressing and dark rendition of the lives of the three characters and that the staff recorded many good-humoured and electrifying shots which, however, did not fit into the final film.

11 The fact that the film is based on a tone poem by Tana Ross corroborates the idea that it is the subjectivity of the narrator's testimony that invests the film with the force of a documentary about the holocaust. According to one of its authors the animated documentary is "the most honest forms of documentary filmmaking" if "the filmmaker is completely upfront about his or her intervention with the subject and if we believe the film to be true it is because we believe the intention was true". See: Yadin 2005. 